\title{
Implementasi Supply Chain Management pada PT Central Proteina Prima Tbk.
}

\author{
Ryan Ariesco Wijaya ${ }^{1}$, Novie Maria Setiawati ${ }^{2}$ \\ ${ }^{12}$ Manajemen Inovasi Universitas Ma Chung, Villa Puncak Tidar Blok N No.1, Malang, Indonesia 65151 \\ Correspondence: Ryan Ariesco Wijaya (ryanariesw09@gmail.com) \\ Received: 020721 - Revised: 220721 - Accepted: 080821 - Published: 280921
}

\begin{abstract}
Abstrak. Perkembangan dunia teknologi dalam globalisasi membawa dampak terhadap persaingan di dunia bisnis. Perusahaan berlomba-lomba untuk berkembangan dan mendapatkan keuntungan yang besar. Supply chain Management sangat dibutuhkan oleh perusahaan untuk membantu proses perkembangan perusahaan. PT Central Proteina Prima Tbk (CP Prima) sebagai perusahaan budidaya udang terdepan di Indonesia melakukan praktek supply chain management khususnya dalam hal pemilihan lokasi, teknologi pembibitan dan otomatisasi. Sebagai upaya dalam menjaga kualitas produksi dan manajemen, department audit internal serta department sistem dan prosedur. PT. Central Proteina Prima, Tbk. telah merancang dan memberlakukan sejumlah kebijakan dan mekanisme terkait pengendalian internal. PT Central Proteina Prima Tbk tidak lepas dari usaha mencapai keberlanjutan (sustainability) dari aspek lingkungan. PT Central Proteina Prima Tbk harus meningkatkan usaha mereka yang berkaitan dengan lingkungan di sepanjang supply chain supaya tetap terjaga. Secara keseluruhan, PT Central Proteina Prima Tbk sudah mengelola supply chain management dari hulu ke hilir dengan baik. Namun, masih perlu meningkatkan pengawasan terhadap kualitas air tambak binaannya. Hal ini menunjukkan bahwa departemen animal health service masih memerlukan SOP pembinaan yang lebih ketat.
\end{abstract}

Kata kunci: supply chain management, teknologi pembibitan, pengendalian internal, pengawasan kualitas, sustainablitity

Citation Format: Wijaya, R.A. \& Setiawati, N.M. (2020). Implementasi Supply Chain Management pada PT Central Proteina Prima Tbk.. Prosiding Seminar Nasional Abdimas Ma Chung (SENAM), 2020, 203-215. 


\section{PENDAHULUAN}

Perkembangan dunia teknologi di era globalisasi tidak hanya membawa dampak terhadap kehidupan sehari-hari melainkan juga persaingan di dunia bisnis. Setiap perusahaan pastinya ingin berkembang dan terus mendapatkan keuntungan. Perusahaan saling berlomba untuk mendapatkan penjualan produk atau komoditas/penjualan yang lebih besar. Indikasi bahwa bisnis identik dengan persaingan dan pengetahuan serta informasi tentang sifat dan karakteristik dari para pesaing merupakan kunci untuk merumuskan persaingan yang akan terjadi kedepannya. Jika melihat tiap bidang usaha yang ada, selalu ada perusahaan yang kinerjanya lebih baik daripada perusahaan-perusahaan lainnya. Ketika perusahaan memiliki kinerja yang lebih baik, perusahaan memiliki keunggulan kompetitif. Salah satu faktor yang menentukan keunggulan kompetitif adalah supply chain management. Supply chain management merupakan pengelolaan berbagai kegiatan yang dimulai dari perolehan bahan mentah, pemrosesan bahan mentah menjadi barang setengah jadi dan barang jadi (Heizer \& Rander, 2015).

Supply chain management sangat dibutuhkan dalam sebuah perusahaan karena dapat membantu dalam proses perkembangannya. Ketatnya persaingan dalam dunia bisnis mengharuskan beberapa perusahaan untuk dapat terus mengembangkan bisnisnya seperti dalam penggunaan teknologi/sistem informasi. Adanya bantuan teknologi/sistem informasi tersebut dapat membantu perusahaan dalam mengembangkan serta menciptakan bisnis yang baru. Adanya teknologi/sistem informasi tersebut dapat terjadi antara pemasok dengan konsumen yang dapat diterapkan pada supply chain management. Untuk dapat melanjutkan kelangsungan bisnis dan unggul dalam persaingan, supply chain management harus memahami kebutuhan dan tuntuan dari konsumen. Pemilihan pemasok dimana dengan pemasok yang tepat akan memberikan garansi kelancaran pasokan aliran barang dan jasa khususnya bahan baku untuk menjaga proses produksi. Pemilihan pemasok merupakan aktivitas penting di bagian pengadaan untuk mencapai keunggulan bersaing.

Pengaruh supply chain management terhadap kesuksesan berlaku pada semua bidang usaha termasuk perikanan. Sebagai negara maritim yang besar, perikanan merupakan sektor yang memberikan sumbangsih besar terhadap pendapatan nasional sehingga pemerintah menggenjot kegiatan ekspor produk perikanan. Sempat menjadi sektor yang kurang mendapatkan perhatian oleh pemerintah, akhirnya supply chain management perikanan mendapatkan pemantauan oleh pemerintah. Pemantauan dilakukan dengan berkoordinasi dengan pihak lain seperti pembudidaya, pelabuhan, eksportir, pengelola cold storage 
(gudang beku), dan pasar. Salah satu perusahaan pengolahan ikan besar di Indonesia adalah PT Central Proteina Prima Tbk.

PT Central Proteina Prima Tbk adalah sebuah perusahaan akuakultur yang bergerak di bidang pakan ikan dan udang, makanan olahan seafood, makanan hewan peliharaan, produk kesehatan binatang air, dan pembibitan ikan dan udang. PT Central Proteina Prima Tbk sebagai perusahaan akuakultur di Indonesia sempat mengalami penurunan signifikan di tahun 2015 dan mengalami kerugian selama 4 tahun beruntun. Hal itu dikarenakan PT Central Proteina Prima Tbk menghadapi tantangan ekspor ke beberapa negara. Saat itu, Indonesia sedang berhadapan dengan pesaing tangguh, yaitu India. Hal ini dikarenakan tingkat produksi India yang sangat tinggi. Terdapat beberapa hal yang masih perlu diperbaiki dalam industri perikanan di Indonesia, antara lain supply chain management, teknologi, dan infrastruktur pada pertambakan udang.

Situasi ini mendorong industri perikanan Indonesia termasuk PT Central Proteina Prima Tbk untuk melakukan inovasi dan meningkatkan kinerjanya. Agar industri perikanan Indonesia termasuk PT Central Proteina Prima Tbk bisa berkompetisi dengan pesaing internasional, PT Central Proteina Prima Tbk melakukan adopsi teknologi dan teknik produksi modern. Dengan pembenahan manajemen dan inovasi supply chain management, CP Prima pada pertengahan tahun 2019 mulai menunjukkan kinerja keuangan yang memuaskan Hal tersebut yang mendasari penulis untuk melakukan analisa lebih jauh mengenai implementasi supply chain management pada PT Central Proteina Prima Tbk. PT Central Proteina Prima Tbk.

\section{METODE PELAKSANAAN}

Metode penelitian ini tergolong sebagai penelitian deskriptif. Metode deskriptif adalah suatu metode dalam meneliti status kelompok manusia, suatu objek, suatu set kondisi, suatu sistem, pemikiran ataupun suatu peristiwa. pada masa sekarang (Nazir, 2011). Penelitian deskriptif merupakan salah satu jenis penelitian yang tujuannya adalah menyajikan gambaran mengenai kondisi sosial secara rinci dan apa adanya. Konten penelitian ini sendiri hanya berupaya untuk memahami fenomena dan realitas yang terdapat di PT Central Proteina Prima Tbk. Data penelitian yang digunakan dalam penelitian ini adalah data sekunder. Data sekunder merupakan data yang mengacu pada informasi yang dikumpulkan dari sumber-sumber yang ada. Data sekunder diperoleh dari buku, jurnal, dan situs internet yang mendukung penelitian (Sekaran \& Bougie, 2017). 


\section{HASIL DAN PEMBAHASAN}

\section{Pemilihan Lokasi Perusahaan}

Salah satu strategi yang perlu diperhatikan perusahaan adalah pemilihan lokasi (Munawaroh, 2013). Pemelihan lokasi ini bisa meliputi lokasi pabrik untuk perusahaan manufaktur maupun lokasi usaha untuk perusahaan jasa atau retail ataupun lokasi perkantorannya. Pemilihan lokasi diperlukan saat perusahaan akan mendirikan usaha baru, memindahkan perusahaan ke lokasi lainnya, atau ekspansi usaha yang telah ada sebelumnya. Pemilihan lokasi sangat penting karena berkaitan dengan besar kecilnya biaya operasi, harga maupun kemampuan bersaing. Lokasi adalah pendorong biaya dan pendapatan sehingga lokasi seringkali memiliki kekuasaaan untuk membuat strategi bisnis perusahaan (Zuliarni \& Hidayat, 2013). Pemilihan lokasi yang strategis bertujuan untuk memaksimalkan keuntungan dari lokasi bari perusahaan. Oleh sebab itu, lokasi usaha merupakan salah satu keputusan bisnis yang harus dibuat secara hati-hati karena pemilihan lokasi usaha yang tepat memberikan kekuatan terhadap suatu strategi bisnis.

PT Central Proteina Prima Tbk mengoperasikan tempat pembibitan udang di berbagai tempat di seluruh Indonesiadan salah satunya di Lampung. Pemilihan lokasi ini didasarkan pada reputasi Provinsi Lampung sebagai pusat produksi udang di Indonesia. Pemerintah berfokus untuk mengangkat perikanan dan kelautan Lampung serta meningkatkan produksi udang Lampung sebagai lumbung udang nasional. Untuk mewujudkan tujuan provinsi Lampung sebagai lumbung gudang nasional, pemerintah provinsi Lampung membangun tambak percontohan. Fokus lain dari Pemerintah Provinsi Lampung adalah membangkitkan kembali kawasan Dipasena, sebuah wilayah produksi udang yang sempat berjaya yang terletak di Rawajitu Timur, TulangBawang, Lampung.

Melihat reputasi Provinsi Lampung, keputusan PT Central Proteina Prima Tbk memilih daerah-daerah tersebut adalah pilihan yang tepat. Harapan dari PT Central Proteina Prima Tbk adalah bisa membangun pabrik yang dekat dengan bahan baku. Dengan membangun penambakan udang di Lampung, PT Central Proteina Prima Tbk bisa menciptakan biaya produksi yang rendah melalui penghematan, ketersediaan bahan baku yang melimpah, inovasi dan kualitas produk, meningkatkan keuntungan, menyenangkan pasar, dan menjadi pemimpin pasar. Keberadaan cold storage yang banyak ditemui di Lampung membantu PT Central Proteina Prima Tbk untuk menyimpan udangnya dalam waktu yang lama. PT Central Proteina Prima Tbk kemudian memanfaatkan lokasi untuk menjual udangnya kepada masyarakat di Lampung. 


\section{Pembibitan}

Produktifitas perikanan di Indonesia terbagi menjadi tiga jenis, diantaranya adalah perikanan tangkap laut, perikanan tangkap PUD (Perairan Umum Daratan) dan perikanan budidaya atau akuakultur (Ghufron et al., 2018). Dari tiga jenis produktifitas perikanan tersebut, yang produktivitasnya terus meningkat secara konsisten tiap tahunnya adalah produktifitas akuakultur. Perikanan akuakultur terus mengalami rata-rata kenaikan sebesar 11,5\% pada tiap tahunnya dari tahun 2012 hingga tahun 2017 (Rahmantya et al., 2018). Walaupun perikanan akuakultur memiliki potensi yang besar serta meningkat secara konsisiten, perikanan akuakultur di sisi lain berisiko tinggi (Saragih, 2015). Hal ini berimbas pada banyaknya pembudidaya yang mengalami gagal panen. Pembudidaya masih kurang dalam pemahaman serta cara-cara budidaya yang diterapkan masih bersifat konvensional (Madhavireddy \& Koteswarrao, 2018).

PT Central Proteina Prima Tbk melakukan pembibitan udang dengan berbagai teknologi. Teknologi tersebut meliputi multi-step filtration systems dengan penggunaan UV dan ozonisasi, produksi pakan dengan bahan dan proses alami, kelengkapan peralatan laboratorium termasuk mesin PCR, dan kontrol kualitas di setiap proses produksinya. PT Central Proteina Prima Tbk menghasilkan benih udang berdasarkan prinsip keberlanjutan (sustainability), keterlacakan (traceability), dan kualitas tinggi sesuai dengan standar global. Perbaikan kualitas udang secara genetik oleh PT Central Proteina Prima Tbk menghasilkan benih udang bebas patogen (SPF) spesifik dengan ketahanan penyakit yang juat dan laju pertumbuhan yang baik. Sertifikat benih dikeluarkan oleh Tim QA-Lab yang indenpenden untuk pemastian keamanan benih dari penyakit.

Salah satu jenis udang yang dilakukan pembibitannya adalah udang putih (litopenaueus vannamei). Berdasarkan Surat Keputusan (SK) Menteri Kelautan dan Perikanan RI. No. 4/2001 tentang Pelepasan Varietas Udang Vaname Sebagai Varietas Unggul, udang putih merupakan udang berkualitas tinggi yang tergolong varietas unggul sehingga mampu mendatangkan peningkatan produksi, pendapatan, maupun kesejahteraan sosial. Kelebihan udang putih antara lain ketahanan yang baik terhadap serangan penyakit, memiliki nafsu makan yang tinggi, memiliki tingkat kelangsungan hidup yang tinggi, laju pertumbuhan yang cepat, mampu hidup dalam lingkungan dengan tingkat kepadatan jumlah ikan yang tinggi, dan waktu pemeliharaan yang terhitung singkat yaitu sekitar 90-100 hari untuk setiap siklusnya. Udang putih sendiri mendominasi volume ekspor udang Indonesia hingga $85 \%$. 
Penelitian (Sitanggang \& Amanda, 2019) membahas tentang kualitas air pada pembesaran udang putih di tiga tambak binaan PT Central Proteina Prima Tbk Medan. Kegiatan yang dilakukan yaitu analisa kualitas air alkalinitas dan kesadahan (hardness) sesuai dengan Standard Operation Procedure (SOP) yang dimiliki Laboratorium animal health service Medan. Pengambilan sampel air diambil pada tiga tambak, antara lain Tambak Sutama, Tambak Ratu, dan Tambak CPF 3. Dari hasil penelitian tersebut, kadar alkalinitas pada ketiga tambak binaan PT. Central Proteina Prima Tbk Medan menunjukkan kadar yang optimal untuk pembesaran udang puth (Litopenaeus vannamei). Namun untuk kadar kesadahan, tambak Sri Ratu ternyata memiliki kadar kesadahan yang tinggi sehingga pergantian air perlu dilakukan untuk menurunkan kadar kesadahan perairan tersebut. Untuk nilai kesadahan kedua tambak binaan lainnya sudah menunjukkan kadar optimal untuk pembesaran udang putih.

Kualitas bibit ikan adalah salah satu faktor penentu keberhasilan budidaya ikan di kolam-kolam pembenihan, keramba jaring apung (KJA), dan pembesaran kolam di air deras. Manajemen pemeliharaan bibit dan induk dimulai dari pengadaan calon induk yang didukung oleh sumber daya manusia, teknologi, serta kelengkapan fasilitas. Riset dalam rangka penciptaan calon induk dengan kualitas lebih baik dan memiliki keunggulan terus dilakukan dengan harapan agar bibit ikan yang dihasilkan mempunyai daya tahan terhadap penyakit serta kecepatan pertumbuhan yang bagus. Pembibitan ikan PT Central Proteina Prima Tbk bekerja sama dengan tim pemasaran pakan ikan untuk pengembangan pola kemitraan pembibitan ikan dengan para pengusaha atau peternak pembibitan rakyat di seluruh Indonesia. Pola kemitraan tersebut sudah berjalan di banyak pulau, antara lain Sumatera, Jawa, Bali, Lombok, Kalimantan. dan Sulawesi.

Untuk jenis ikan yang dilaksanakan pembibitannya adalah nila hitam Black Prima (BP), bibit nila merah Red Prima (RP) dan bibit lele CP. Jumlah kemitraan pembibitan ikan PT Central Proteina Prima Tbk diiringi dengan pembinaan teknis secara rutin. Teknisiteknisi pendamping yang terlatih dari PT Central Proteina Prima Tbk diperbantukan di mitramitra pembibitan dengan tujuan bisa menghasilkan bibit ikan berkualitas tinggi dan sesuai ketentuan standar. Pemantauan SOP pembibitan selalu dilakukan mulai dari perawatan induk, proses pembenihan, pengendalian bibit ikan, hingga distribusi bibit ikan ke konsumen. Pemantauan kesehatan ikan dan kualitas air juga dilakukan secara rutin sebagai bentuk kerja sama tim. 


\section{Departemen}

Di PT Central Proteina Prima Tbk sendiri, divisi technical research \& development (TRD) mempunyai tugas untuk memastikan pengembangan berkelanjutan dari teknologi akuakultur milik PT Central Proteina Prima Tbk beserta penyebarannya, memastikan kualitas bibit udang dan ikan, dan memberikan dukungan teknis bagi para pembudidaya PT Central Proteina Prima Tbk. Penciptaan produk baru merupakan salah satu cara bagi PT Central Proteina Prima Tbk untuk mengungguli kompetitior. Research and Development (R\&D) merupakan sebuah metode penelitian yang dilakukan secara sengaja dan sistematis, dengan tujuan menemukan, menguji, menghasilkan, mengembangkan, maupun memperbaiki efektivitas produk, model, maupun strategi/model yang lebih efektif, efisien, baru, unggul, bermakna, dan produktif (Putra, 2015).

PT Central Proteina Prima Tbk memiliki departemen quality assurance (QA)/kualitas mutu yang bertugas memastikan kualitas dari benih udang berkualitas tinggi yang diproduksi di pembenihan milik PT Central Proteina Prima Tbk. Departemen quality assurance memastikan bahwa proses produksi telah sesuai dengan standar dan persyaratan yang telah ditentukan. Kualitas mutu sistem kontrol kualitas dan pemantauan kesehatan udang PT Central Proteina Prima Tbk mampu menyeleksi benih udang dengan pertumbuhan terbaik dan status kesehatan benih udang yang layak panen dan didistribusi ke tambak. Dengan begitu, PT Central Proteina Prima Tbk bisa mencegah adanya produk berkualitas rendah atau kerusakan produk.

Mutu produk dilihat dari bagaimana fungsi dan kondisi fisik produk tersebut mamu memenuhi kebutuhan, kinginan, dan selera konsumen dengan memuaskan sesuai nilai uang yang telah dikeluarkan. Mutu produk terbilang baik jika mampu memberik kepuasan kepada konsumen dan demikian pula sebaliknya. Dalam menciptakan perubahan mutu produk, PT Central Proteina Prima Tbk perlu melakukan perubahan dan peningkatan proses produksi, keterampilan tenaga kerja, tugas dalam kegiatan produksi, dan perubahan lingkungan perusahaan supaya produk PT Central Proteina Prima Tbk bisa menjawab bahkan melampaui ekspetasi konsumen.

Laboratorium PT Central Proteina Prima Tbk dilengkapi dengan peralatan canggih serta alat diagnostik untuk menentukan status kesehatan udang secara akurat dan andal. Laboratorium diagnostik molekuler PT Central Proteina Prima Tbk juga berpartisipasi dalam uji banding (ring test) PCR internasional yang diselenggarakan oleh University of Arizona secara rutin. Hal tersebut merupakan upaya dari PT Central Proteina Prima Tbk dalam 
pemeliharaan dan pemastian kualitas analisis di laboratorium PT Central Proteina Prima Tbk. Pemantauan status kesehatan udang dan ikan secara berkelanjutan di tambak dan kualitas air serta penyesuaian teknis secara cepat akan menurunkan tingkat risiko kegagalan produksi dan akhirnya terjadi peningkatan produktivitas budidaya.

Departemen animal health service membentuk beberapa laboratorium regional beserta tim layanan teknis untuk melakukan pemantauan dan dukungan teknis yang kompeten dan andal bagi pembudidaya PT Central Proteina Prima Tbk. PT Central Proteina Prima Tbk dengan peternak bersama-sama mencari solusi atas munculnya masalah selama budidaya. Selain itu, luasnya cakupan pelayanan PT Central Proteina Prima Tbk, intensifitas layanan pemantauan, dan keandalan keterampilan pemecahan masalah menempatkan PT Central Proteina Prima Tbk pada posisi sebagai salah satu pengelola kesehatan udang dan ikan yang andal di industri budidaya perikanan Indonesia.

\section{Otomatisasi}

Otomatisasi merupakan kreasi dan penerapan teknologi yang bertujuan untuk memproduksi dan mengirimkan barang dan jasa dengan campur tangan manusia seminimal mungkin. Penerapan teknologi, teknik, dan proses otomasi mampu meningkatkan efisiensi, kecepatan, dan keandalan dalam pengerjaan banyak tugas yang sebelumnya dilakukan oleh manusia. Otomatisasi telah banyak digunakan di berbagai bidang seperti transportasi, manufaktur, pertahanan, operasi, fasilitas, dan teknologi informasi. Pada umumnya, otomatisasi diterapkan dengan tujuan meminimalkan tenaga kerja atau menggantikan manusia dalam tugas yang sifatnya berulang-ulang. Di zaman sekarang, sebagian besar pabrik menerapkan otomatisasi dalam bentuk perakitan robotik. Keberadaan manusia hanya diperlukan untuk menentukan proses dan mengawasinya. Sementara itu, perakitan berbagai komponen diserahkan kepada mesin yang mengubah bahan mentah menjadi barang jadi secara otomatis. Dampak otomatisasi semakin meningkat seiring berkembangnya teknologi.

Otomatisasi berperan dalam peningkatan produktivitas dunia industri selama puluhan tahun. Otomatisasi sangat membantu industri dalam menghemat waktu dan biaya. Otomatisasi memastikan pengiriman produk dan layanan berjalan dengan efektif. Di sisi lain, otomatisasi menyebabkan kebutuhan akan tenaga kerja manusia menjadi tidak diperlukan dan akhirnya dipindahkan. Otomatisasi memiliki dampak negatif pada pekerjaan yang tidak memerlukan pelatihan atau keterampilan tertentu. Pada tingkat yang lebih jauh, otomatisasi menambah jumlah pengangguran. Secara keseluruhan, efek ekonomi positif dalam hal 
industri baru dan pekerjaan yang tersedia jauh lebih besar daripada yang negativf. Meskipun ada kemajuan dalam otomatisasi, tenaga kerja manusia tetap dibutuhkan meskipun mesin dan sistem informasi dapat melakukan banyak tugas. Tenaga ahli dalam pembuatan aplikasi dan pemantauan teknologi otomatisasi sangat diminati.

Pabrik produksi pakan milik PT Central Proteina Prima Tbk sudah menggunakan sistem otomatisasi, antara lain asupan bahan baku, penggilingan kasar, batching \& dry mixing, penggilingan halus, pencampuran basah, extrusion and pelleting, pengeringan, pendinginan, serta oil coating and packing. Dengan sistem otomatisasi, PT Central Proteina Prima Tbk mengontrol dan memantau setiap tahap produksi dengan tujuan untuk memastikan bahan baku sudah digunakan sesuai dengan formula dan prosedur standar yang berlaku. Hal ini juga berperan dalam mencegah terjadinya human error. Sistem otomatisasi milik PT Central Proteina Prima Tbk mampu menghasilkan produk pakan yang berkualitas secara konsisten.

Sistem otomatisasi ini juga membantukan operator PT Central Proteina Prima Tbk dalam melacak tiap produk dengan menggunakan laporan dan tren fitur yang telah disediakan. Dengan begitu, kegiatan distribusi produk dapat berlangsung dengan aman. Pabrik pakan PT Central Proteina Prima Tbk juga dilengkapi dengan kontrol pengawasan dan monitoring data, BITWISE, dan programmable logic controller (PLC) system untuk mengoperasikan mesin-mesin otomatis. Keberadaan mesin otomatis ini mampu menerapkan pengawasan dan quality control dengan baik. Otomatisasi telah diaplikasikan pada semua pabrik pakan ikan PT Central Proteina Prima Tbk.

\section{Pengendalian Kualitas}

Produk dapat memuaskan pelanggan jika kualitas produk yang diberikan mampu memenuhi keinginan pelanggan. Kualitas produk merupakan faktor penting yang menentukan apakah produk dipilih oleh pelanggan atau tidak. Demi mencapai kualitas produk, perusahaan harus menerapkan pengendalian kualitas dalam proses produksinya. Pengendalian merupakan ketentuan apa yang harus dilaksanakan, menilai dan mengoreksi pelaksanaannya bila perlu dengan maksud supaya pelaksanaan pekerjaan sesuai dengan rencana semula (Ayuni et al., 2012). Kualitas bersifat conformance to requirement, yaitu sesuai dengan yang disyaratkan atau distandarkan (Nasution, 2015). Suatu produk memiliki kualitas apabila sesuai dengan standar kualitas yang telah ditentukan. Standar kualitas meliputi bahan baku, proses produksi dan produk jadi. Kualitas produk pun sangat 
bergantung pada proses, manusia, dan sistem secara keseluruhan (Azmiyati \& Hidayat, 2016).

Terdapat empat faktor yang mempengaruhi pengendalian kualitas yang dilakukan perusahaan, antara lain kemampuan proses, spesifikasi yang berlaku, tingkat kesesuaian yang diterima, dan biaya kualitas (Zulian, 2013). Produk PT Central Proteina Prima Tbk diproduksi dan dikemas melalui sistem pemantauan dan kontrol kualitas yang dapat diandalkan dan sangat ketat. Produk PT Central Proteina Prima Tbk tidak terkontaminasi oleh benda asing atau zat kimia yang berbahaya seperti antibiotik atau zat pada tingkat tertentu yang tidak bisa diterima oleh kontaminan lainnya sehingga aman saat dikonsumsi manusia karena diproduksi di lingkungan yang aman dan terpelihara dengan baik. Produk PT Central Proteina Prima Tbk dapat dilacak ke asal-usul bahan baku seafood.

Bahan baku yang masuk akan diperiksa terlebih dahulu secara menyeluruh dengan menggunakan 2 metode yaitu sampling dan laboratorium tes. Pemeriksaan dilakukan baik di pabrik pemasok sebelum proses pengiriman maupun di pabrik pakan PT Central Proteina Prima Tbk. Persediaan bahan baku yang disimpan di gudang diperiksa secara teratur dan diuji sebelum penggunaan secara menyeluruh. Bahan baku yang disimpan di gudang diperiksa untuk memastikan bahwa bahan baku berada dalam tingkat kualitas yang baik sebelum digunakan dengan menerapkan prinsip FIFO. Semua parameter yang terkait data kualitas produk akan didokumentasikan untuk semua batch pada pakan yang diproduksi. Semua proses produksi dan data kualitas akan didokumentasikan sehingga produk dapat dilacak dengan baik.

\section{Sistem Pengendalian Internal}

Pengendalian internal adalah seperangkat kebijakan dan prosedur untuk melindungi aset atau kekayaan perusahaan dari segala bentuk tindakan penyalahgunaan, menjamin tersedianya informasi akuntansi perusahaan yang akurat, serta memastikan bahwa semua ketentuan hukum/Undang-Undang serta kebijakan manajemen telah dipatuhi atau dijalankan sebagaimana mestinya oleh seluruh karyawan perusahaan (Hery, 2016). Pengendalian internal merupakan sebuah proses yang dibangun oleh manajemen perusahaan dengan tujuan mencapai efektivitas dan efisiensi operasional serta kepatuhan tiap individu terhadap peraturan dan hukum yang berlaku. Dalam kebijakan PT Central Proteina Prima Tbk atas sistem pengendalian internal, disebutkan bahwa departemen audit internal memiliki tugas untuk melakukan pengujian dan pemeriksaan terhadap sistem pengendalian internal 
perusahaan. Setelah melakukan pengujian dan pemeriksaan, departemen audit internal melaporkan pelaksanaan tugasnya kepada direktur utama.

Departemen audit internal serta departemen sistem dan prosedur telah merancang dan memberlakukan sejumlah kebijakan dan mekanisme terkait pengendalian internal. Dari aspek lingkungan pengendalian internal, mereka melakukan pengawasan atas akses data dalam perencanaan sumber daya perusahaan/enterprise resource planning (ERP) dan juga review terhadap pembagian tugas dan kewenangan setiap bagian kerja sesuai fungsinya yang tercatat dalam aplikasi ERP. Mereka juga memiliki kebijakan untuk merancang dan melakukan review pada aplikasi yang berhubungan dengan sistem teknologi informasi. Dari aspek aktivitas pengendalian, mereka memberikan saran atas penyusunan kebijakan tata kelola perusahaan/corporate governance policy, kebijakan manajemen/management policy dan Standar Operasional Prosedur (SOP). Demi penerapan SOP yang benar, mereka juga merancang sistem monitoring untuk mendeteksi penyimpangan penerapan SOP yang berbasis Aplikasi ERP. Mereka juga memiliki wewenang untuk memberikan rekomendasi dan saran atas pengembangan sejumlah aplikasi terkait dengan teknologi informasi.

Dari aspek pemantauan, mereka bekerjasama dengan departemen keuangan dan akuntansi mengatur adanya evaluasi secara berkesinambungan atas implementasi SOP. Mereka juga melakukan monitoring yang berkesinambungan atas tindakan perbaikan yang belum dilakukan (follow up on corrective action) oleh auditee sesuai laporan audit. Melalui audit internal, PT Central Proteina Prima Tbk mendorong berbagai upaya untuk meningkatkan sistem pengendalian internal yang efektif. Audit internal memiliki peran untuk mengevaluasi efektifitas dan kecakupan pengendalian internal yang dilakukan oleh pihak manajemen. Evaluasi dilakukan secara rutin dan hasil evaluasi nantinya digunakan sebagai acuan dalam perbaikan sistem dan kebijakan yang lebih efektif demi pencapaian target perusahaan.

\section{KESIMPULAN}

PT Central Proteina Prima Tbk telah mengembangkan supply chain management yang efektif. Supply chain management yang efektif dan inovatif untul memperkuat posisinya di pasar dan mendatangkan keuntungan lebih banyak. Pelaku dalam supply chain PT Central Proteina Prima Tbk meliputi tambak, laboratorium, pabrik, pengecer, konsumen, dan UMKM. Namun, PT Central Proteina Prima Tbk masih perlu meningkatkan pengawasan 
terhadap kualitas air tambak binaannya. Hal ini menunjukkan bahwa departemen animal health service memerlukan SOP pembinaan yang lebih ketat.

\section{DAFTAR PUSTAKA}

Ayuni, D., Siswandaru, K., \& Nupikso, G. (2012). Analisis Penerapan Statistical Quality Control pada Beban Usaha PT. PLN. Jurnal Organisasi dan Manajemen. Vol. 8 No. 1: 22-31.

Azmiyati, S., \& Hidayat, S. (2016). Pengukuran Kinerja Rantai Pasok pada PT. Louserindo Megah Permai Menggunakan Model SCOR dan FAHP. Jurnal AlAzhar Indonesia Seri Sains dan Teknologi, Vol. 3 No. 4, 163-170.

Ghufron, M., Lamid, M., Sari, P. D. W., \& Suprapto, H. (2018). Teknik Pembesaran Udang Vaname (Litopenaeus Vannamei) Pada Tambak Pendampingan Pt Central Proteina Prima Tbk Di Desa Randutatah, Kecamatan Paiton, Probolinggo, Jawa Timur. Journal of Aquaculture and Fish Health, Vol. 7 No. 2.

Heizer, J., \& Render, B. (2015), Manajemen Operasi: Manajemen Keberlangsungan dan Rantai Pasokan, Edisi 11. Salemba Empat: Jakarta.

Hery. (2016). Akuntansi Dasar 1 dan 2. Jakarta: PT Grasindo.

https://www.cpp.co.id/id

Indariyanti, N., Oktaviana, A., \& Valentine, R.Y. (2018). Pemanfaatan Limbah Industri Fillet Patin untuki Produksi Usaha Makanan Kreatif pada UMKM Kejora Desa Margaagung Jati Agung Lampung Selatan. Prosiding Seminar Nasional Penerapan IPTEKS, pp. 62-65.

Madhavireddy, V., \& Koteswarrao, B. (2018). Smart Water Quality Monitoring System Using Iot Technology. International Journal of Engineering \& Technology, Vol. 7.

Mahrom, Y.D.S. \& Kosim, B. (2019). Analisis Potensi Financial Distress pada PT. Central Proteina Prima, Tbk. Jurnal Manajemen dan Bisnis. Vol 4, No 1, 624-636.

Manambing, M.F., Tumade, P. dan Sumarauw, J.S.B. (2014). Analisis Perencanaan Supply Chain Management (SCM) pada PT. Sinar Galesong Pratama. Jurnal Emba: Jurnal Riset Ekonomi, Manajemen, Bisnis dan Akuntansi. Vol. 2. No. 2, 1570-1578.

Munawaroh, M. (2013). Manajemen Operasi. Yogyakarta. LP3M UMY.

Nasution, N. (2015). Dasar - Dasar Manajemen Produksi. Yogyakarta: BPFE.

Nazir, M, (2011), Metode Penelitian. Jakarta.

Purnamasari, I., Purnama, D., \& Utami, M.A.F. (2017). Pertumbuhan Udang Vaname (Litopenaeus Vannamei) di Tambak Intensif. Jurnal Enggano, Vol. 2 No. 1, pp. 5867.

Rahmantya, K. F., Asianto, A. D., Wahyuni, T., Wibowo, D., \& Zunianto, A. K. (2018). Buku Pintar Kelautan dan Perikanan. Jakarta: Pusat Data, Statistik, dan Informasi.

Rani, P. \& Rahmawati, D. (2008). Analisis Penerapatn E-Business Studi Kasus pada PT. Sinar Mas Agro Resource and Techology (SMART), Tbk. Jurnal Pendidikan Akuntansi Indonesia. Vol. 4 No. 2, 52-59.

Saragih, N. S., Sukiyono, K., \& Cahyadinata, I. (2015). Risk Analysis of Production and Income the Shrimp Cultivation of the People in UrbanVillage Labuhan Deli, Sub District Medan Marelan, Medan City. AGRISEP, Vol. 14 No. 1, pp. 39-52.

Sitanggang, L.P., \& Amanda, L. (2019). Analisa Kualitas Air Alkalinitas dan Kesadahan (Hardness) pada Pembesaran Udang Putih (Litopenaeus Vannamei) di Laboratorium Animal Health Service Binaan PT Central Proteina Prima Tbk Medan. Jurnal Penelitian Terapan Perikanan dan Kelautan, Vol. 1 No. 1, pp. 54-60. 
Surat Keputusan (SK) Menteri Kelautan dan Perikanan RI. No. 4/2001 tentang Pelepasan Varietas Udang Vaname Sebagai Varietas Unggul

Zulian, Y. (2013). Manajemen Kualitas Produk dan Jasa. Yogyakarta: Ekonisia.

Zuliarni, S., \& Hidayat, R.T. (2013). Analisis Faktor Pertimbangan Pebisnis Restoran Kelas Kecil di Lingkungan Kampus Universitas Riau dalam Pemilihan Lokasi Usaha. Jurnal Aplikasi Bisnis, Vol. 3 No. 2, pp. 100-119.

(C) 2021 by authors. Content on this article is licensed under a Creative Commons Attribution 4.0 International license. (http://creativecommons.org/licenses/by/4.0/). 